\title{
28. BIOTURBATION IN MIDDLE BATHYAL, CENOZOIC NANNOFOSSIL OOZES AND CHALKS, SOUTHWEST PACIFIC ${ }^{1}$
}

\author{
Campbell S. Nelson, University of Waikato, Hamilton, New Zealand ${ }^{2}$
}

\begin{abstract}
The high-quality cores obtained on Leg 90 have enabled preliminary qualitative study of the trace fossils in middle to late Cenozoic oozes and chalks at sites from equatorial to subantarctic latitudes in the southwest Pacific. Cores are dominated by a range of biogenic hieroglyphs that are in the main taxonomically nondiagnostic and are identified principally by subtle color contrasts with the host sediment, or by pyritization. Structures include abundant mottles, blebs and spots, common streaks and wisps, and rarer threads, tubes, rinds, halos, rings, and pockets. Planolites-like and possibly Trichichnus burrows occur, and below some critical sub-bottom depth in most holes a Planolites-ChondritesZoophycos ichnofaunal assemblage is developed. The megascopically apparent intensity of bioturbation in cores is summarized on stratigraphic logs for each site, and ranges widely both within and between sites. Controlling factors were unlikely to have been variations in either substrate character or water depth as primary sediments were almost wholly pure (foraminifer-bearing) nannofossil oozes deposited at middle bathyal (1-2 km) depths. Instead, fluctuations in sedimentation rates and in the rate of supply of organic nutrients at the seafloor were probably the influential controls on the degree of sediment bioturbation. Overall increases in both these parameters in the Neogene can explain the upward disappearance of the Planolites-Chondrites-Zoophycos assemblage in cores. Fundamental causes probably relate to the Cenozoic evolution and fluctuations in position and level of productivity of surface and intermediate-depth water masses in the southwest Pacific.
\end{abstract}

\section{INTRODUCTION}

Trace fossils provide useful information about ecology, sedimentation processes, water depth, and depositional environments of sediments (e.g., Frey, 1975; Basan, 1978). In deep-sea cores they are often the only or dominant structures in the sediments and may be the only preserved record of benthic faunal activity. The understanding of the nature and paleoecology of deep-sea fossil communities has resulted from several detailed studies of trace fossils in DSDP cores from a range of oceanic environments (e.g., Tracey et al., 1971; Fullman et al., 1973; Piper and Schrader, 1973; van der Lingen, 1973; Warme et al., 1973; Ekdale, 1978, 1980; Okado, 1980; McMillen and Lundberg, 1982). Useful overviews of trace fossils and their significance in DSDP sediments generally have been made by Chamberlain (1975) for the Pacific Ocean, and Ekdale (1977) for all oceans.

DSDP Leg 90 obtained a traverse of nine middle to late Cenozoic cores (Sites 586 to 594) between equatorial and northern subantarctic water masses in the southwest Pacific (Fig. 1). All the sites are located at relatively shallow water depths of between 1000 and $2200 \mathrm{~m}$, principally on Lord Howe Rise in the Tasman Sea. Drilled sequences are dominantly pure calcareous oozes and chalks, mainly continuously deposited and uncomplicated by unconformities in their Neogene-Quaternary parts. Lord Howe Rise had subsided everywhere to present-day upper to middle bathyal depths by the middle Eocene (introductory chapter, this volume), so that the cored sedi-

\footnotetext{
${ }^{1}$ Kennett, J. P., von der Borch, C. C., et al., Init. Repts. DSDP, 90: Washington (U.S. Govt, Printing Office). land.
}

ments were deposited at depths comparable to those of the present drill sites. Most cores were obtained with the hydraulic piston corer and extended core barrel systems (introductory chapter, this volume), which provided both high (average $\sim 90 \%$ ) core recovery and good quality sections with minimal core disturbance, even in soft oozes.

These high-quality cores provided an excellent opportunity to record the biogenic structures in Cenozoic foraminifer-bearing nannofossil oozes deposited on open ocean platforms at middle bathyal $(1000-2000 \mathrm{~m})$ depths (classification scheme of Edwards, 1979) across a wide range of latitudes. Previously, the rotary drilling method used on Legs 21 and 29 in this region had mainly smeared or destroyed trace fossils in the thick ooze sequences, restricting observations to the more indurated sediments (van der Lingen, 1973). Moreover, in Chamberlain's (1975) general review of trace fossils in Pacific DSDP cores only 4 of his 38 sites yielding bioturbation data came from water depths as shallow as middle bathyal, and none were as shallow as most Leg 90 sites, from 1000 to $1500 \mathrm{~m}$ depth. Since a major aim of DSDP Leg 90 is to gain detailed information on Neogene paleoceanography in the southwest Pacific from high-resolution biostratigraphic and isotopic studies of the sediments, the intention is to provide future researchers with some information on bioturbation in the cores.

\section{METHODS}

A specialized study of bioturbation has not been attempted. In describing core lithologies, the shipboard sedimentologists arbitrarily classified the extent of bioturbation as minor $(<30 \%)$, moderate $(30-$ $60 \%$ ), or intense $(>60 \%)$ and noted certain other properties such as color, geometry, and location of trace fossils. After the cruise, a complete set of black-and-white core photographs was obtained and, in conjunction with the shipboard core descriptions, was used to determine the nature of visible trace fossil markings in the sediments and to 


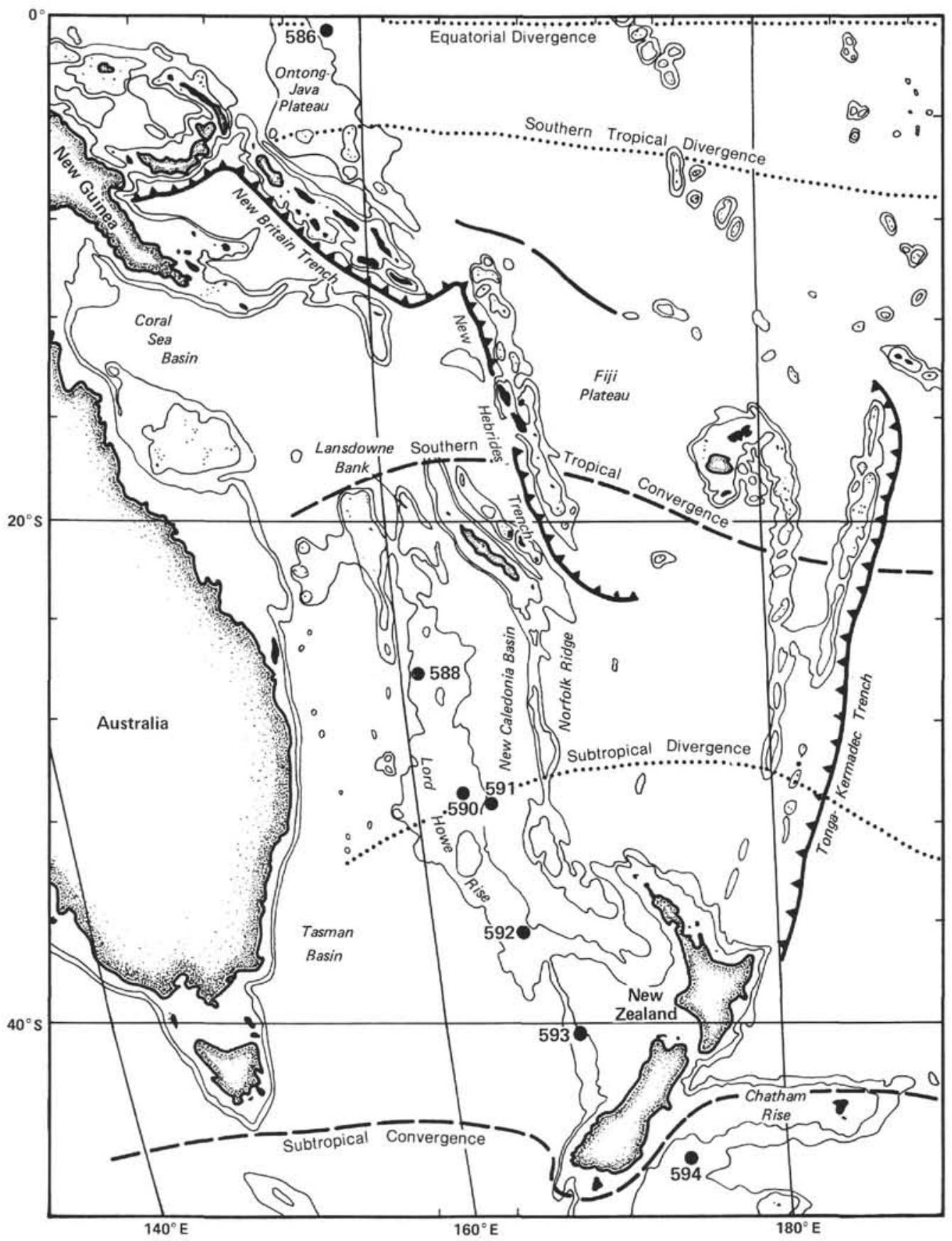

Figure 1. Location of DSDP Leg 90 sites in the southwest Pacific for which bioturbation data are presented. The approximate positions of major water mass boundaries are taken from Knox (1970). Depth contours are for 1000 and $2000 \mathrm{~m}$.

construct logs showing the apparent degree of bioturbation in Leg 90 cores from seven principal sites $(586,588,590-594)$. This megascopic approach to describing the degree of bioturbation is potentially subject to several errors, but is nevertheless that normally used when logging DSDP core materials generally. For example, a totally featureless ooze can indicate complete homogenization of the sediment by meiofaunal burrowers, but outward proof of this is visibly lacking and the ooze would probably be logged as showing little evidence of bioturbation. Burrow preservation is a complex function of the rates of burrow production and destruction, the rate of sediment burial, the type and strength of sediment, and its early diagenetic history (Berger et al., 1979). Diagenesis, in particular, commonly imparts visual color contrasts between the organic traces and the surrounding burrowed or nonburrowed sediment. This is the principal basis for differentiating bioturbation in Leg 90 cores. The visual extent of bioturbation in Leg 90 cores has been placed within an arbitrary 10-point scale in which 3, 6 , and 9 correspond approximately to the shipboard categories of minor, moderate, and intense bioturbation, respectively (Fig. 2). It is stressed, however, that only with more specialized core study, such as by Xray radiography (e.g., Werner and Wetzel, 1981), can a more truly quantitative assessment of bioturbation be attempted.

\section{DESCRIPTION AND GENERAL DISTRIBUTION OF SPECIFIC BIOGENIC TRACES}

Burrow traces are ubiquitous in Leg 90 cores, but only rarely are they assignable to a specific ichnogenus. They 

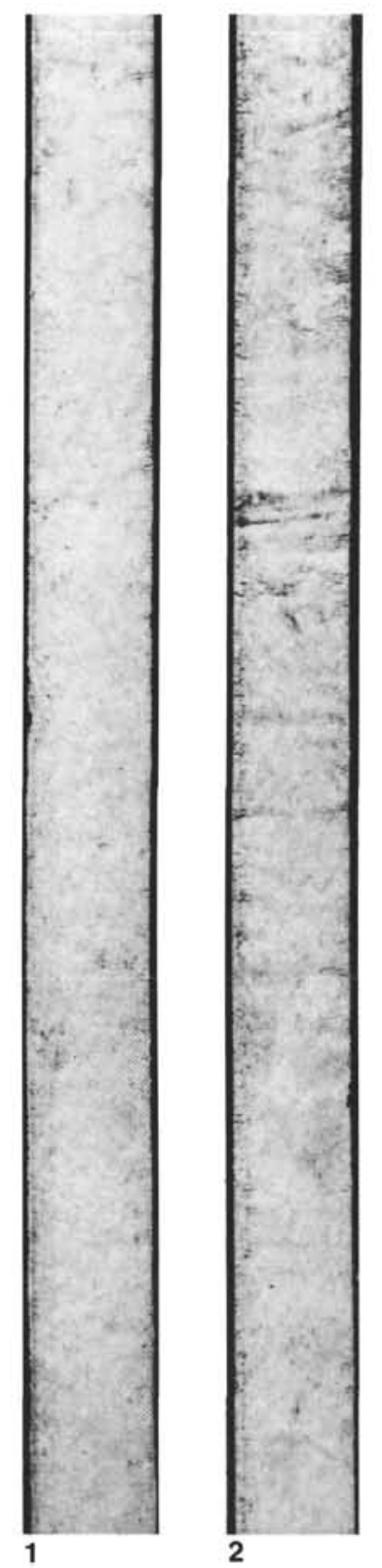
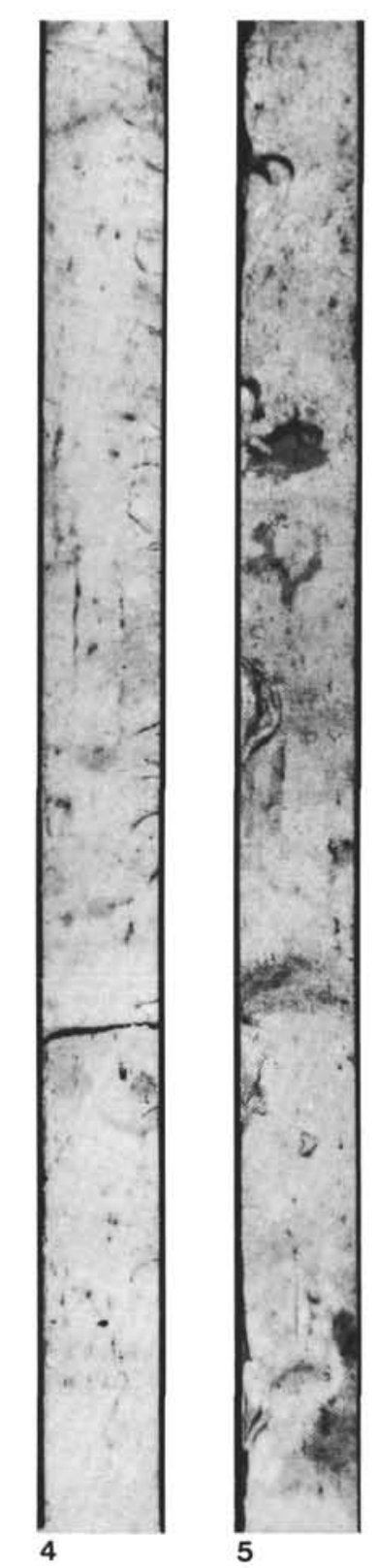

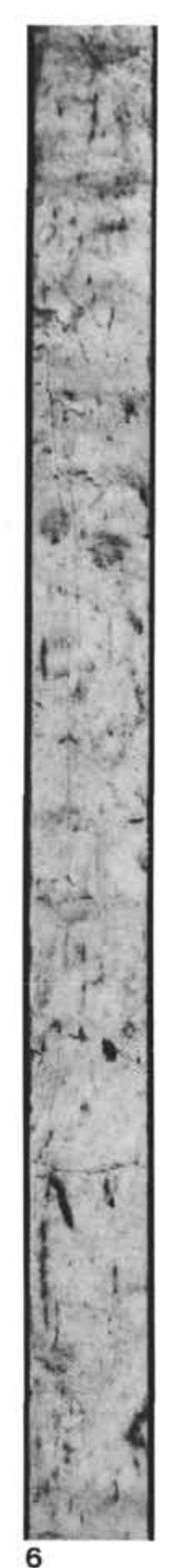

6

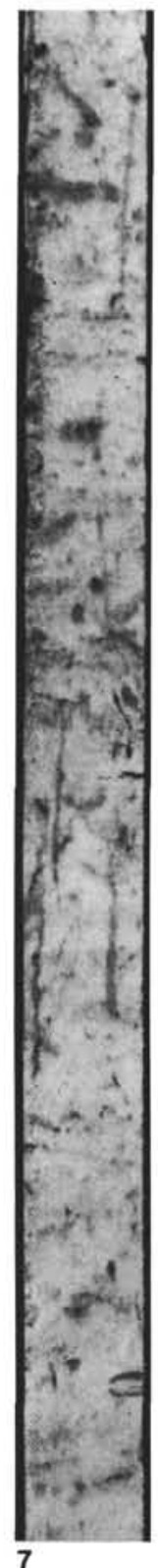

7

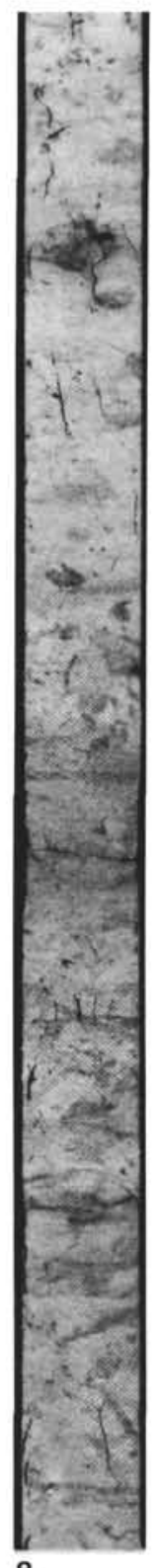

8

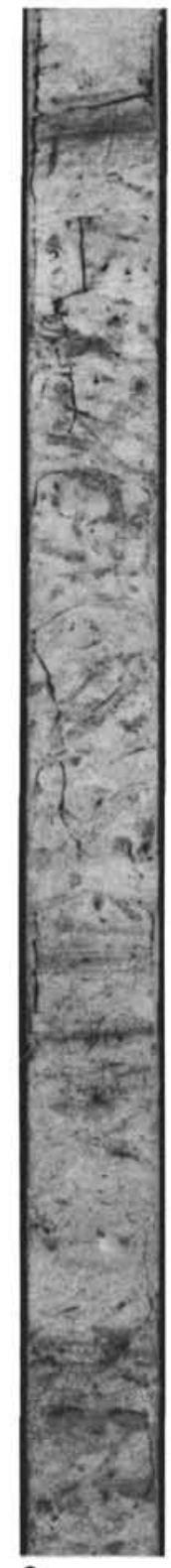

9

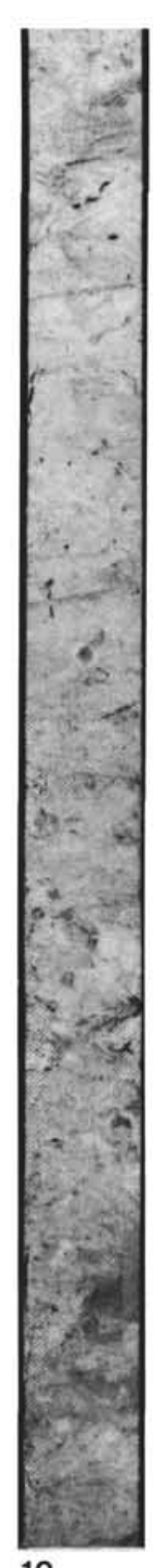

10

igure 2. Typical range of bioturbation structures in Leg 90 calcareous oozes and chalks. Note the preponderance of taxonomically nondiagnostic biogenic hieroglyphs and mottles, although examples of Planolites and Zoophycos are evident with a magnifying lens in Samples H to J. Based principally on the intensity of color contrast patterns, the sequence from A to J is arranged in order of megascopically apparent increasing intensity of sediment bioturbation (see discussion under Methods). Core locations are 1. 588A-1-6, 65-145 cm; 2. 588-22-4, 60-140 cm; 3. 588-11-1, 60$140 \mathrm{~cm} ; 4$. 588-17-1, 10-90 cm; 5. 588-5-5, 0-80 cm; 6. 586B-12-2, 20-100 cm; 7. 586B-15-1, 10-90 cm; 8. 590B-33-6, 30-110 cm; 9. 590B-45-4, 45-125 cm; 10. 590B-37-5, 70-150 cm. 
are recognized primarily by color and/or subtle textural contrasts with the surrounding sediment. The host calcareous oozes and chalks are mainly white (N9), very light gray (N8), or light gray (N7), whereas burrows are mainly yellowish gray $(5 Y 8 / 1,5 Y 7 / 2)$, greenish gray (5GY 6/1, 5GY 7/1, 5GY 7/2, 5GY 8/1), pale olive (10Y $6 / 2$ ), or light to dark gray (N7 to N3). Smear slides from the burrowed sediment and the host sediment seldom reveal major differences in composition or texture. Some mottles with yellowish hues include more foraminiferal material than the host nannofossil-dominated oozes; those with greenish hues may contain concentrations of altered volcanic ash components (Gardner, Nelson, et al., this volume); and dark gray mottles may be relatively enriched in authigenic iron sulfides, commonly pyrite framboids.

The geometry of burrows in split cores is highly variable with a preponderance of mainly nondiagnostic biogenic hieroglyphs, informally described as spots, blebs, pockets, threads, tubes, streaks, wisps, eddies, rinds, halos, rings, and circular, ovoid, or irregular mottles. Their boundaries with the host sediment are mainly diffuse and often abruptly color gradational. Some characteristics of specific traces are mentioned in the following and illustrated in Figures 2 and 3, and in Plate 1.

\section{Spots and Blebs:}

Spots and blebs, often formed of pyritized sediment, range up to a few millimeters across and may be isolated "pods" or sections through short threads or tubes. They are ubiquitous and common in Leg 90 cores, especially throughout the upper Miocene-Quaternary oozes at Sites 586 and 588, and the Pliocene-Quaternary oozes at Sites 590 and 591 . The strong tendency to pyritization suggests that at least some of these structures may be crosssections of Trichichnus burrows (Werner and Wetzel, 1981). Others may represent fecal pellets or disrupted fecal strings.

\section{Pockets:}

Pockets are typically a few to several millimeters in size, with irregular or vertically elliptical shapes, infilled by mud-depleted sediment, commonly foraminiferal material and pyrite, sometimes preferentially cemented by ?celestite (e.g., Cores 593-11, 593-12, and 593-13). They are generally rare but are conspicuous in the PlioceneQuaternary oozes at the southern sites (591-594). Highly selective sediment sorting within capsular structures is indicated, but the organism responsible is unknown.

\section{Threads and Tubes:}

Threads and tubes have small diameters $(0.2-2.0 \mathrm{~mm})$, range up to several centimeters long, rarely to $30 \mathrm{~cm}$, and consist dominantly of pyritized sediment. They are ubiquitous but rare in Leg 90 cores, are most obvious in the upper Neogene oozes at northern sites (586-590), and some may be Trichichnus burrows. Bundles of fine tubes sometimes form the nucleus of pyritized nodules in the sediments (Fig. 4).

\section{Streaks, Wisps, and Eddies:}

Nebulous streaks and wisps are mainly horizontally to obliquely oriented and, along with occasional eddies, may be mainly biodeformational structures associated with the indiscriminant tracking, burrowing, and churning of surficial sediment layers (e.g., Werner and Wetzel, 1981). They are detected by generally subtle diagenetic color contrasts in the sediment and are one of the most common bioturbate structures in Leg 90 cores, particularly at Sites 586 through 591 . They are of unknown taxonomic affinity.

\section{Rinds, Halos, and Rings:}

Rinds and halos are (sub)circular sections of cylindrical burrows, typically 5 to $40 \mathrm{~mm}$ across, defined by diagenetic color contrasts at the margins of burrows. Diffusion color rings, resembling Liesegang rings, are sometimes also developed about the burrows, rarely as far as $10-15 \mathrm{~cm}$ from the (inferred) burrow shaft. Gray, green, or purple hues dominate, suggesting they have formed by mobilization and precipitation of iron compounds under more or less reducing Eh conditions around the preferred sites of sulfate reduction provided by the organic-rich burrows. Rinds, halos, and rings occur infrequently in all cores, and are most common at Sites 586, 590 , and 591 . They are taxonomically nondiagnostic, but are widely reported from deep-sea cores (e.g., Chamberlain, 1975, 1978).

\section{Mottles:}

Circular and ovoid mottles are typically $5-30 \mathrm{~mm}$ or more across, internally structureless, and are the cross or oblique sections of mainly horizontal to inclined burrows of similar width. They are nearly always associated with similarly sized or larger irregular blebs, patches and mottles, and rarely with more vertically oriented shafts up to $10-15 \mathrm{~cm}$ long (e.g., Fig. 3). Blebs and mottles are the dominant bioturbation structure in Leg 90 sediments and occur to a greater or lesser extent in practically every core studied. They can be difficult to discern because of diffuse contacts with, and only subtle color differences from, the host sediment. In some firmer oozes they appear to be sites of preferential cementation (e.g., Fig. 3H), Plate 1, Fig. 7; Cores 593-29 and 594-36). Those mottles representing subhorizontal burrows with subcircular cross-sections are a form of Planolites (e.g., Plate 1, Figs. 2, 7, 9-12) referred to as Planolites-like in the core barrel descriptions (Site chapters, this volume). They occur sporadically at all sites in oozes of Miocene to Quaternary age and are most obvious in several of the Pliocene cores from Sites 590 and 591.

\section{Planolites-Chondrites-Zoophycos Association:}

Only three trace fossil genera have been positively identified in Leg 90 cores: Planolites, Chondrites, and Zoophycos. The morphologic characteristics of these traces are similar to those previously detailed by several workers (e.g., Hantzschel, 1975; Chamberlain, 1975, 1978; 


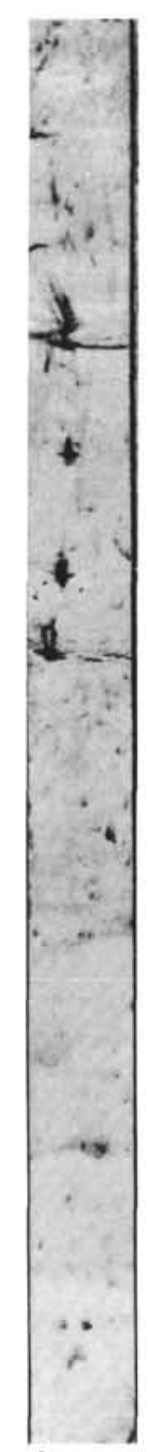

A

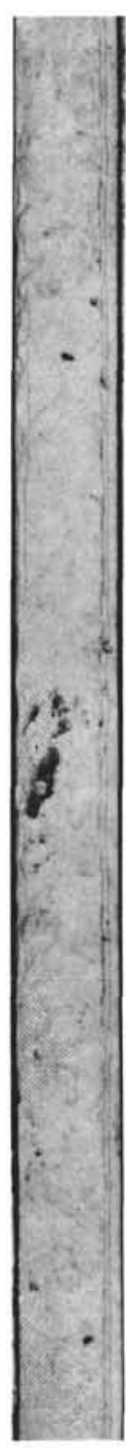

B
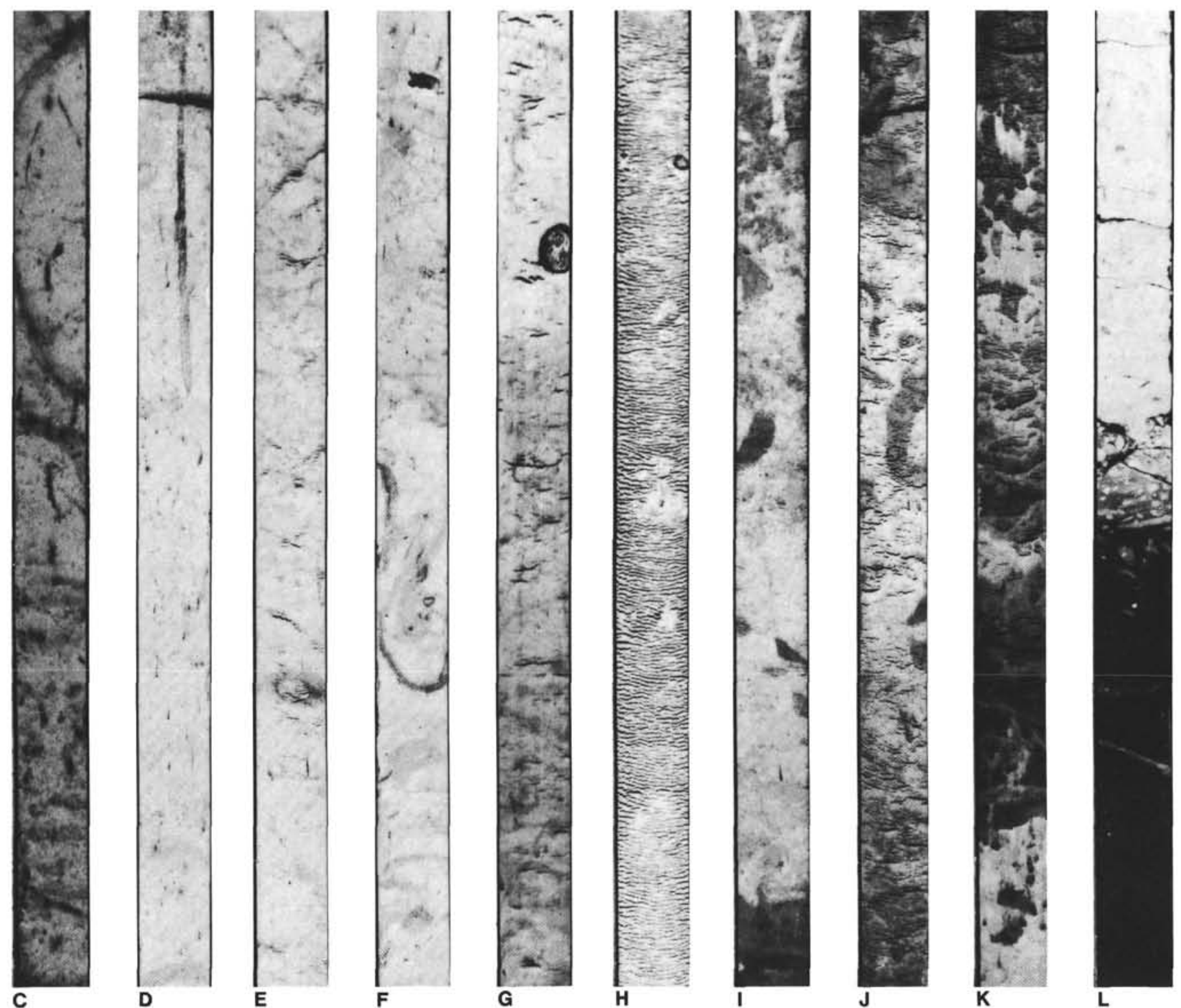

Figure 3. Examples of some specific biogenic traces occurring commonly in Leg 90 calcareous oozes and chalks. A. 588-17-3, 10-90 cm, showing scattered pyritized spots and blebs; B. 592-13-3, $55-135 \mathrm{~cm}$, showing foraminifer-rich pockets midway down the section; C. 586B-21-3, $65-145 \mathrm{~cm}$, showing common pyritized spots, threads and streaks, irregular blebs and mottles, and a large diameter diffusion color ring; D. 588-11-6, 5-85 cm, showing scattered pyritized spots and a long tube; E. 591-29-5, 5-85 cm, showing solitary Planolites-like halo burrow; F. 590B-7-3, 45-125 $\mathrm{cm}$, showing biogenic streaks, wisps and mottles, a color diffusion ring structure, and pyritized spots and blebs; G. 591-24-4, 70-150 cm, showing diffuse mottles and a solitary Planolites-like rind burrow with reburrowed fill; H. 594-36-2, 5-85 cm, showing preferentially cemented Planolites-like burrows in stiff ooze, one including a color diffusion ring; I. 594-15-6, 10-90 cm, showing irregular and Planolites-like mottles across the contacts between pelagic (light) and hemipelagic (dark) sediment and within the pelagic interval; J. 594-16-1, 50-130 $\mathrm{cm}$, as for I; K. 594-20-1, $45-125 \mathrm{~cm}$, as for I showing severe biogenic disruption and displacement of sediment across the lithologic boundaries; L. 594A-23-1, 55-135 cm, showing well developed Planolites, Chondrites, and Zoophycos burrows at the top of a silty turbidite (dark) in chalk (light), the later preserving mainly scattered Planolites burrows and diffuse mottles. 


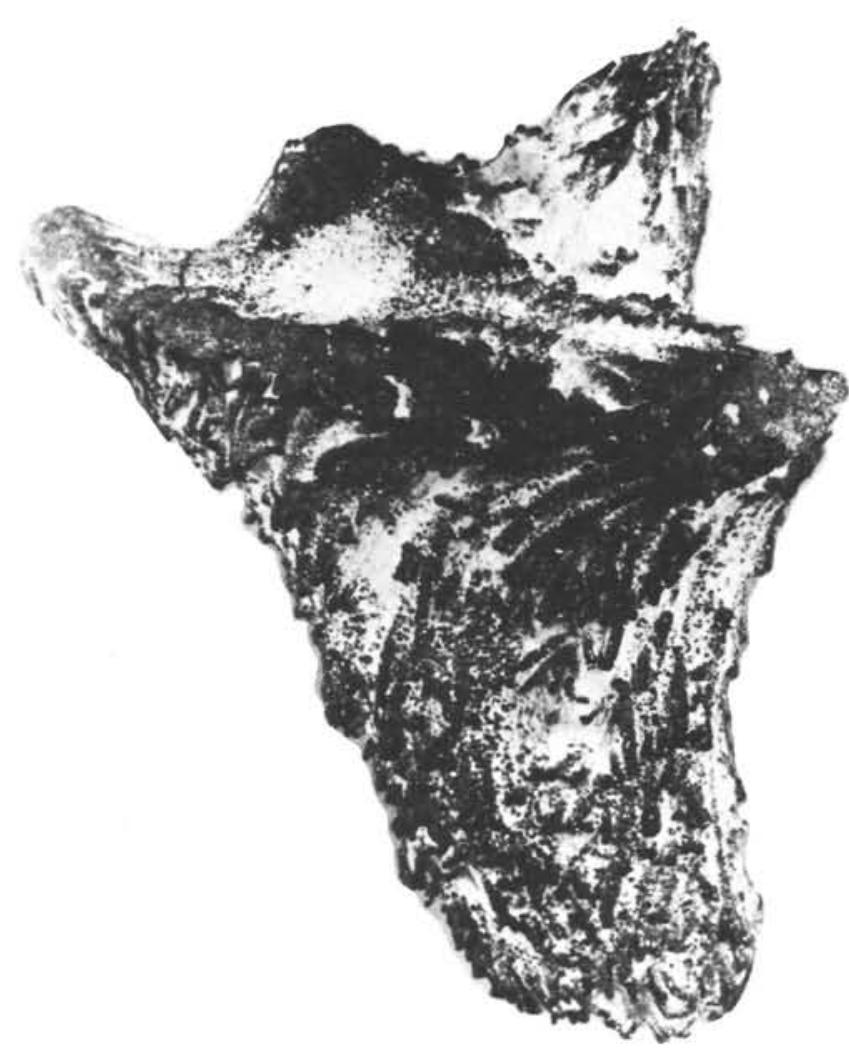

Figure 4. A spectacular 5-cm-long pyritized nodule from Sample 588$17-2,143-148 \mathrm{~cm}$, consisting of tapering bundles of overlapping fine tubes of unknown taxonomy.

Ekdale, 1977). Planolites is a simple, subhorizontal to inclined burrow seen mainly as subcircular, elliptical, or lenticular shapes in cross-section (e.g., Plate 1, Figs. 2, 7, 9-12). Chondrites comprises a three-dimensional dendritic network of obliquely to horizontally orientated burrows, typically only 1-2 mm in diameter, spreading down and out from a central shaft. On split core faces it usually appears as tiny ovoid blebs, a millimeter or so across, with associated small Y-shaped branching tubes (Plate 1, Figs. 6, 9-12). Zoophycos consists of a horizontal or inclined web or spreiten (up to $8 \mathrm{~mm}$ thick) of burrowed and back-filled sediment producing characteristic crescentic arcs in split core faces (Plate 1, Figs. 1, 5, 6, 10, 12).

Two striking features concerning Planolites, Chondrites, and Zoophycos are noted for Leg 90 cores. First, although the Planolites-like traces discussed previously can and do occur by themselves, the Planolites, Zoophy$\cos$, and Chondrites traces typically occur in association. In no core has only Zoophycos or only Chondrites been identified without the nearby presence of the other trace or of Planolites (Plate 1). Thus a definite Planolites-Chondrites-Zoophycos assemblage exists in Leg 90 sediments. Second, this assemblage is not uniformly distributed through the cores, but appears to be absent at each site down to some critical sub-bottom depth below which it persists to a greater or lesser extent to the bottom of the drilled sequence (Table 1; Fig. 5). This critical depth level differs from site to site, generally becomes progressively deeper from north to south, and varies widely in age in a nonsystematic way from as young as latest Mio- cene (Site 590) to as old as latest Eocene (Site 593). Possible reasons for this distribution pattern are discussed later.

\section{BIOTURBATION HISTORY AND SOME ENVIRONMENTAL RELATIONSHIPS}

Given the reservations outlined earlier, the apparent degree of bioturbation in Leg 90 cores from each site is summarized on stratigraphic logs in Figure 5. Also plotted are the general lithology, age, and sedimentation rates, as well as the sub-bottom depth below which the Planolites-Chondrites-Zoophycos assemblages occurs in cores.

\section{Site $586(2207 \mathrm{~m})$ : Tropical}

Bioturbation here is moderate to moderately intense throughout the upper Miocene to Quaternary sequence of foraminifer-bearing nannofossil oozes. Overall, the apparent degree of bioturbation is consistently greater than in comparably aged lithologies at all other sites, despite the persistently moderate rates of sedimentation. This may relate to uniformly high productivity in the water column at Site 586, located beneath the Equatorial Divergence (Fig. 1). The most intensely bioturbated inter$\mathrm{val}$, from the late late Miocene to early early Pliocene, coincides with the lowest rates of sedimentation in the section. Nondescript biogenic hieroglyphs, often pyritized, completely dominate the sequence. The PlanolitesChondrites-Zoophycos assemblage was not encountered at Site 586.

\section{Site 588 (1533 m): Warm Subtropical}

The sequence is a foraminifer-bearing nannofossil ooze or chalk of middle Eocene to Quaternary age. Bioturbation appears moderately intense in the middle Eocene to early Miocene, drops to very low in the middle Miocene, and fluctuates from low to moderate in the late Miocene to Quaternary. Nondiagnostic biogenic markings, commonly pyritized in the late Miocene to Quaternary inter$\mathrm{val}$, dominate. The Planolites-Chondrites-Zoophycos assemblage is restricted to the moderately bioturbated premiddle Miocene chalks, appearing about $60 \mathrm{~m}$ below the ooze/chalk transition level. No clear relation exists between apparent degree of bioturbation and rates of sedimentation, although the middle Miocene to Quaternary interval of reduced bioturbation coincides with a general increase in the mass accumulation rate of sediments compared to pre-middle Miocene values. The bioturbation curve may reflect productivity variations associated with changes in intermediate water masses during the Neogene. This is exemplified by several significant changes in the benthic foraminiferal assemblages at Site 588 (Site 588 chapter, this volume), especially across the early/middle Miocene boundary and within the Pliocene, periods of notable changes in degree of sediment bioturbation.

\section{Site 590 (1299 m): Transitional Warm Subtropical to Temperate}

This late early Miocene to Quaternary sequence consists of foraminifer, foraminifer-bearing, and pure nannofossil oozes and chalks. The apparent degree of bioturbation is moderate in the early Miocene, generally in- 
Table 1. Sub-bottom depth and age of first downhole appearance of the Planolites-Chrondrites-

Zoophycos trace fossil assemblage and of the ooze/chalk transition level at drill sites on Leg 90 .

\begin{tabular}{|c|c|c|c|c|c|c|c|c|}
\hline \multirow[b]{2}{*}{ Site } & \multirow{2}{*}{$\begin{array}{c}\text { Water } \\
\text { depth (m) }\end{array}$} & \multirow{2}{*}{$\begin{array}{c}\text { Total core } \\
\text { penetration }(\mathrm{m})\end{array}$} & \multicolumn{3}{|c|}{$\begin{array}{l}\text { First appearance downhole of } \\
\text { Planolites-Chrondrites-Zoophycos }\end{array}$} & \multicolumn{3}{|c|}{$\begin{array}{l}\text { Level of ooze/chalk } \\
\text { transition }\end{array}$} \\
\hline & & & Core & Depth (m) & $\sim$ Age (m.y.) & Core & Depth (m) & Age (m.y.) \\
\hline 586 & 2207 & 305.3 & - & - & - & $25 \mathrm{~A}$ & $? 260$ & $? 8$ \\
\hline 588 & 1533 & 488.1 & $1 \mathrm{C}$ & 306 & 17 & $2 \mathrm{~A}$ & 245 & 13 \\
\hline 590 & 1299 & 499.1 & $28 \mathrm{~B}$ & 251 & 7.5 & $30 \mathrm{~B}$ & 269 & 8 \\
\hline 591 & 2131 & 500.4 & $4 \mathrm{~B}$ & 299 & 9.5 & $3 B$ & 290 & 9 \\
\hline 592 & 1098 & 388.5 & 34 & 312 & 35 & 30 & 273 & 17 \\
\hline 593 & 1068 & 571.5 & 60 & 562 & 40 & 60 & 562 & 40 \\
\hline 594 & 1204 & 639.5 & $13 \mathrm{~A}$ & 505 & 14 & 50 & 476 & 13 \\
\hline
\end{tabular}

Note: $-=$ not present

tense in the middle and early late Miocene, and low to moderate thereafter. The rather abrupt upward change from moderately high to generally low amounts of bioturbation within the late Miocene interval coincides with a significant increase in sediment accumulation rate since the middle late Miocene. It also corresponds to the ooze/ chalk transition at $269 \mathrm{~m}$ sub-bottom depth and, in the latest Miocene, to a distinctive cooling as temperate waters migrated northward across the area (Site 590 chapter, this volume). Nondiagnostic biogenic markings dominate the record and are joined by many examples of Planolites, Zoophycos, and rarer Chondrites traces below $251 \mathrm{~m}$. The increased amount of bioturbation of the entire Neogene sequence compared to both more northern (Site 588) and southern (Site 592) sites may relate to an overall higher delivery rate of organic material to the ocean floor at the site, which lies below the Subtropical Divergence in the Tasman Sea (Fig. 1).

\section{Site 591 (2131 m): Transitional Warm Subtropical to Temperate}

This late early Miocene to Quaternary sequence is comparable in age and lithology to adjacent Site 590, but was deposited in deeper $(\sim 2000 \mathrm{~m})$ water. The apparent intensity of bioturbation is consistently low to moderate throughout and bears little relation to either variations in rates of sedimentation at the site or to the bioturbation log at the nearby shallower Site 590. Perhaps the supply of organic nutrients at the seafloor was influenced independently by the development and history of an intermediate water mass at the site, as suggested by important shifts in benthic foraminiferal assemblages in the late middle Miocene, early late Miocene, latest Miocene, and late Pliocene (Site 591 chapter, this volume). Biogenic hieroglyphs continue to dominate the trace fossil record and are joined by scattered Planolites, Zoophycos, and occasional Chondrites below 299 m sub-bottom, $9 \mathrm{~m}$ below the ooze/chalk transition.

\section{Site 592 (1098 m): Cool Temperate}

The late Eocene to Quaternary foraminifer-bearing and purer nannofossil oozes (and chalks) show major differences in their apparent degree of bioturbation. They are moderately intensely bioturbated in the Paleogene, show a decrease through the early Miocene to very low levels of bioturbation in the middle Miocene, moderate values in the late Miocene, a drop to mainly low values in the early Pliocene, and a return to moderately intense values in the late Pliocene and Quaternary. The overall reduction in sediment accumulation rates at Site 592 compared to the more northerly sites is not matched by an apparent increase in sediment bioturbation, although a rough inverse relationship occurs between bioturbation and sedimentation rates for the late Neogene-Quaternary interval of core. The Planolites-Chondrites-Zoophycos assemblage is evident only in the Eocene-Oligocene oozes and chalks below the well-defined PaleogeneNeogene unconformity at $\sim 306 \mathrm{~m}$ sub-bottom. Persistence of mild bottom current activity at this site throughout the entire Neogene-Quaternary is suggested both by relatively thin sequences and by stratigraphic wedging on the seismic profile (Site 592 chapter, this volume) and may account for the reduced rates of both sediment accumulation and bioturbation at Site 592 .

\section{Site 593 (1068 m): Cool Temperate}

This late Eocene to Quaternary sequence comprises foraminifer-bearing nannofossil ooze that grades to nannofossil ooze (and chalk) with depth. Despite some significant changes in sedimentation rates, the apparent degree of bioturbation is mainly uniformly low throughout the core. Only in the late Pliocene-Quaternary and late Eocene-Oligocene intervals, when sedimentation rates were relatively reduced, does the intensity of bioturbation increase. Nondiagnostic traces are ubiquitous and the Planolites-Chondrites-Zoophycos assemblage appears only in the upper Eocene chalk at the bottom of the hole, beneath a conspicuous volcanogenic deposit marking the Eocene/Oligocene boundary (Nelson, Briggs, et al., this volume).

\section{Site 594 (1204 m): Northern Subantarctic}

The core comprises a foraminifer-bearing to pure nannofossil ooze (chalk) of latest early Miocene to late Miocene age, below a thick $(\sim 180 \mathrm{~m})$ Pliocene-Quaternary sequence of alternating pelagic and hemipelagic oozes. The apparent degree of bioturbation ranges widely and is moderate in the late early Miocene to early middle Miocene, very low in the late middle Miocene, increases to moderate values by the close of the Miocene, is moderately intense in the Pliocene, and fluctuates from low to moderately intense throughout the Quaternary. The generally low values through the late middle Miocene and late Miocene occur during relatively high rates 

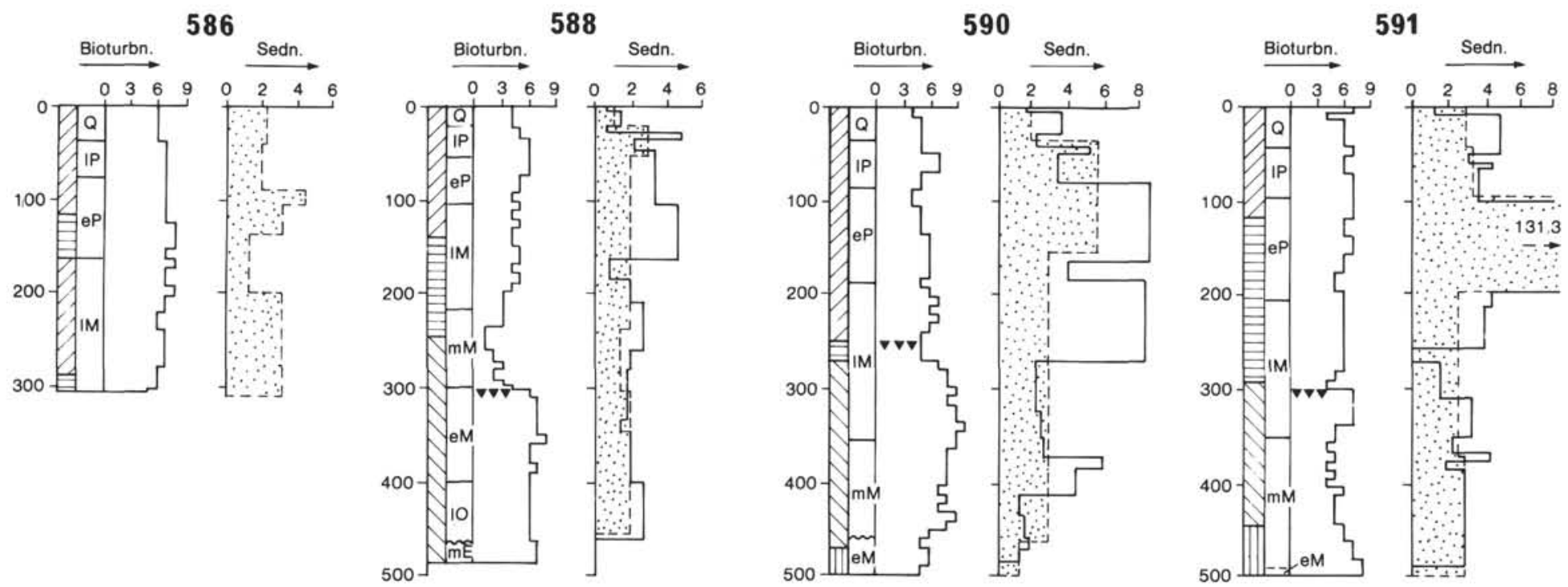

Lithology

DSoft calcareous ooze
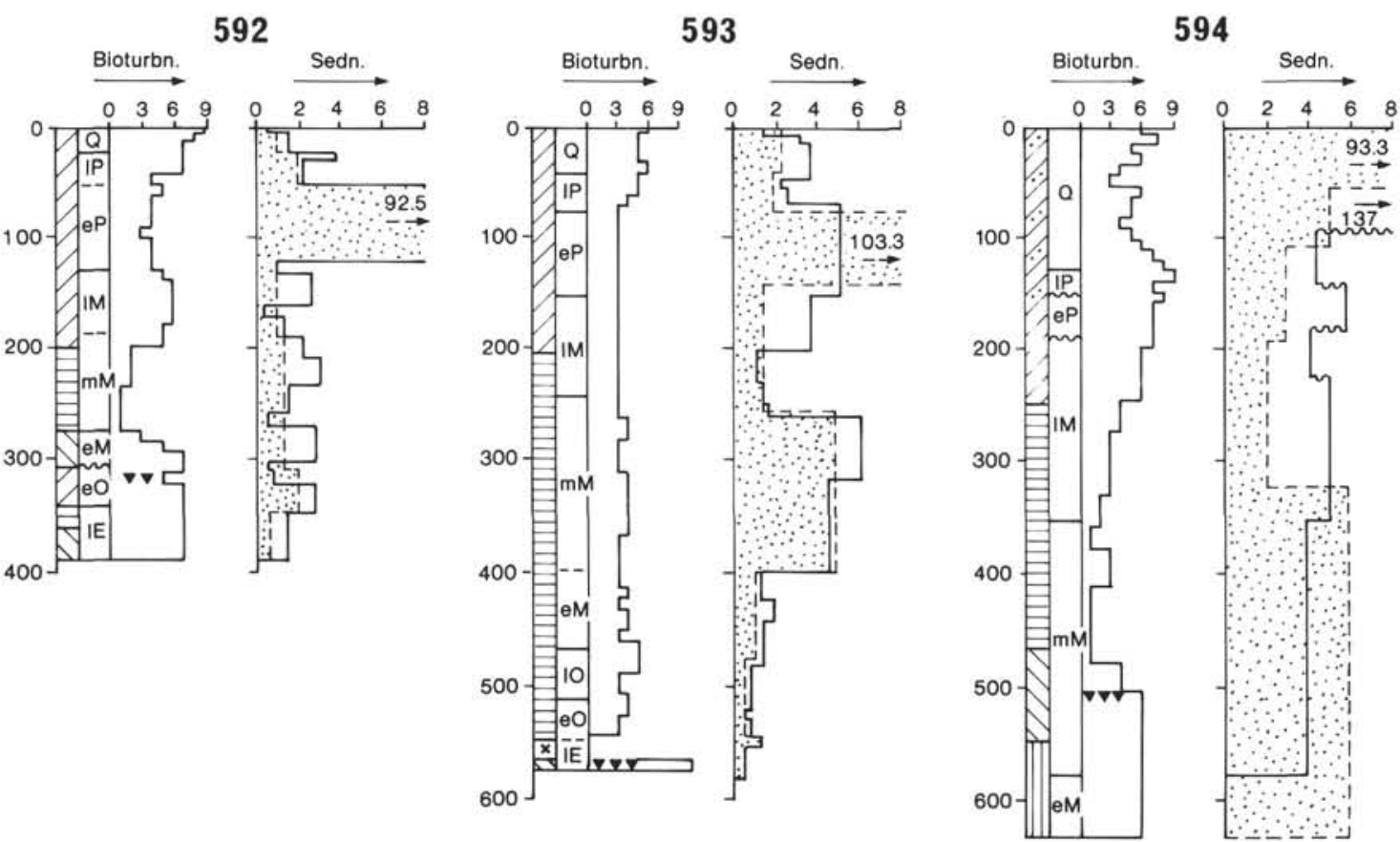

Figure 5. Stratigraphic logs showing the changing relative intensity (increases from 0 to 9) of megascopically visible bioturbation (see Fig. 2) in Leg 90 cores, and the level below which the Planolites-Chondrites-Zoophycos assemblage occurs at each site, Sediment age (E, Eocene; O, Oligocene; M, Miocene, Pl, Pliocene; $\mathrm{Q}$, Quaternary; e, early; m, middle; 1 , late), degree of induration, and rate of sedimentation, both uncorrected for sediment porosity ( $\mathrm{m} \times 10 / \mathrm{m} . \mathrm{y}$.$) and as mass accumulation rates ( \mathrm{g}$ $\times 10^{3} / \mathrm{cm}^{2}$ per m.y.), are also shown (data from site chapters, this volume). 
of ooze accumulation, especially compared with similarly aged oozes at other sites. The fluctuating but moderately high degree of bioturbation in the Pliocene-Quaternary, despite the rapid rates of sediment accumulation, may be related to nutrient enrichment at the seafloor associated with hemipelagic sedimentation and/or the proximity of the Subtropical Convergence (Fig. 1). The record is dominated by biogenic hieroglyphs, especially diffuse color blebs and mottles, which are conspicuous across the boundaries of the rapidly alternating pelagic-hemipelagic oozes in the upper part of the core. The Planolites-Chondrites-Zoophycos assemblage occurs only below $505 \mathrm{~m}$ sub-bottom depth, about $30 \mathrm{~m}$ below the ooze/chalk transition level, and is especially evident in silt-bearing clayey chalk turbidite interbeds. These show a pronounced habitat stratification of infaunal burrow types in their upper levels, with Planolites between 0 and about $5 \mathrm{~cm}$, Chondrites to depths of $10 \mathrm{~cm}$, and Zoophycos to depths of $15-20 \mathrm{~cm}$ in the beds (Fig. 3L) and Plate 1, Figs. 11, 12). The ecologic stratification is similar to that described by Seilacher (1978) for the burrowed tops of turbidites and by Werner and Wetzel (1981) in their story sequence model of bioturbation in oceanic sediments generally.

\section{DISCUSSION}

The character of bioturbation in Leg 90 cores is similar at all sites and is dominated by mainly nondiagnostic biogenic traces and Planolites-like burrow mottles, with variable development of a Planolites-Chondrites-Zoophycos ichnofaunal assemblage at depth in the cores. However, the megascopically apparent intensity of bioturbation in sediments ranges widely, both within and between sites. These variations are unlikely to have been controlled primarily by significant differences in substrate (i.e., grain size, composition, consistency, or induration), water depth, or redox conditions since the primary sediments were nearly all (foraminifer-bearing) nannofossil oozes deposited in aerobic bottom waters at middle bathyal depths ( $\sim 1000-2000 \mathrm{~m}$; see site chapters, this volume).

The two most important factors influencing the bioturbation record are considered to have been the rate of sediment accumulation and the availability of organic nutrients at the seafloor. As specifically mentioned earlier, a rough inverse relationship is evident between sedimentation rate and sediment bioturbation over several stratigraphic intervals at the various sites (Fig. 5). For example, at Site 590 the overall apparent decrease in intensity of bioturbation since the late late Miocene is associated with a significant increase in sediment accumulation rates, and the sharp increase in bioturbation in the late Pliocene-Quaternary oozes at Site 592 corresponds with a sudden drop in sedimentation rates. However, in Leg 90 sediments generally, the apparent bioturbation response does vary within and between cores for otherwise similar changes in the rate of sediment accumulaiisn. Moreover, sometimes no obvious correlation occurs between rates of sedimentation and intensity of bioturbation. In these instances the rate of supply of organic matter to the ocean floor may have been an influential factor. With due regard for sedimentation rates, it is noticeable that the apparent degree of bioturbation in the late Neogene-Quaternary oozes is proportionately greater at those sites (Sites 586, 590, 591, and 594) located near the boundary of contrasting water masses in the southwest Pacific than at intervening sites (Fig. 1). Oceanic fronts are commonly regions of enhanced primary productivity in the water column (Knox, 1970; Lisitzin, 1972; Bradford and Roberts, 1978; Bradford, 1983), and it can be inferred that there will be a corresponding increase in the availability of organic nutrients at the seafloor in their vicinity (Suess, 1980). Under these conditions the potential exists for an increase both in the number and diversity of benthic fauna and in their extent and depth of sediment reworking.

It is possible, therefore, that the more significant spatial and temporal variations recorded by the bioturbation logs for Leg 90 sediments are related to the Cenozoic history of development, migration, and level of fertility of the various surface and intermediate-depth water masses in the southwest Pacific (e.g., Rochford, 1960a, b; Knox, 1970). The relationship is supported by a degree of parallelism between the bioturbation record and major shifts in the nature and diversity of microfossil assemblages at several sites (e.g., see earlier discussion of Sites 588 and 591). However, only with high resolution micropaleontologic and isotope studies of the core sediments, perhaps in conjunction with organic carbon measurements (e.g., Müller and Suess, 1979), can the interrelationships between water masses, organic nutrient availability, sedimentation rates, and intensity of sediment bioturbation be investigated more closely.

An outstanding problem in Leg 90 sediments concerns the interpretation of the distribution of the PlanolitesChondrites-Zoophycos trace fossil assemblage and, specifically, why it appears to be restricted to the lower part of holes (Fig. 5). The fact that it occurs mainly below the ooze/chalk transition depth (Table 1) originally suggested that diagenetic enhancement controlled the distribution, but several factors argue against a purely diagenetic control:

1. Many chalk cores lack the assemblage, sometimes over long intervals (e.g., Cores 588A-2 to 588A-13).

2. The assemblage is well developed in both soft and firm oozes below the first ooze/chalk transition level at Site 592 and also occurs in firm oozes immediately above the transition level at Site 590.

3. Scattered occurrences of Planolites and Planoliteslike burrows are evident by themselves in both oozes and chalks at most sites (e.g., Plate 1).

4. Although several examples of the Planolites-Chondrites-Zoophycos assemblage in Leg 90 chalks occur in association with rare turbidite or volcanic ash interbeds, where their burrow fills are emphasized by strong color contrasts (e.g., see Plate 1, Figs. 9-12), the majority are differentiated by the same yellowish or greenish gray tones that distinguish the biogenic traces generally in Leg 90 oozes and chalks (compare Figs. 1 and 2 with Plate 1, Figs. 1, 5, 6, 8). Consequently, it is unlikely that the distinctive chevron traces of Zoophycos, for example, if genuinely common in the oozes, could have totally escaped being identified during the detailed examination and description of $2-3 \mathrm{~km}$ of core sediments. 
An age control based on extinction of the animals responsible for the trace fossils cannot explain the upward disappearance of the association because (a) there is considerable variation in age (late Eocene to late Miocene) of the last occurrence of the trace fossil association in the different holes (Table 1), and (b) the stratigraphic range of each of the three trace fossils concerned extends to the Recent (Chamberlain, 1978).

One is forced to seek some environmental reason(s) for the apparent upward disappearance of the Planolites-Chondrites-Zoophycos assemblage in cores. It is notable that at each site, irrespective of age, the assemblage occurs in mainly moderately to moderately intensely bioturbated sequences deposited under conditions of relatively low rates of sediment accumulation for that site. Disappearance of the assemblage coincides generally with a significant decrease in the apparent intensity of bioturbation and an overall increase in the long-term rate of sediment accumulation. On this basis, and using the environmental preferences established by Werner and Wetzel (1981) for the same trace fossils on the modern North Atlantic slope, a possible explanation is given in Figure 6 for the upward loss of the Planolites-Chondrites-Zoophycos assemblage and its replacement by Planolites(-like) burrows and nondiagnostic biogenic hieroglyphs in Leg 90 cores. Note especially that depositional depths and substrate characteristics remain similar throughout, and that the major controls are variations in rate of sediment accumulation and/or supply of organic nutrients at the seafloor. It has been mentioned earlier that these factors are probably linked to the evolution and history of contrasting surface and intermediate water masses in the southwest Pacific. If this is so, then detailed studies of the character, distribution, and intensity of bioturbation in oceanic cores can make a useful contribution to the developing science of paleoceanography.

\section{ACKNOWLEDGMENTS}

I thank Janet Bradford and Keith Probert (N. Z. Oceanographic Institute, Wellington) for helpful discussion on the topics of bioturbation and primary productivity, and Gerrit van der Lingen (N. Z. Geological Survey, Christchurch), Wolfgang Berger (Scripps Institution of Oceanography), and Allan Ekdale (Department of Geology and Geophysics, University of Utah, Salt Lake City) for their useful comments on a draft of the paper.

\section{REFERENCES}

Basan, P. (Ed.), 1978. Trace Fossil Concepts: Tulsa (Society of Economic Paleontologists and Mineralogists Short Course 5).

Berger, W. H., Ekdale, A. A., and Bryant, P. P., 1979. Selective preservation of burrows in deep-sea carbonates. Mar. Geol., 32:205230.

Bradford, J. M., 1983. Plankton and primary productivity in the vicinity of Chatham Rise. N.Z.O.I. Oceanog. Summary, 21:1-14.

Bradford, J. M., and Roberts, P. E., 1978. Distribution of reactive phosphorus and plankton in relation to upwelling and surface circulation around New Zealand. N.Z. J. Mar. Freshw. Res., 12:1-15.

Chamberlain, C. K., 1975. Trace fossils in DSDP cores of the Pacific. J. Paleontol., 49:1074-1096.

, 1978. Recognition of trace fossils in cores. In Basan, P. (Ed.), Trace Fossil Concepts: Tulsa (Society of Economic Paleontologists and Mineralogists Short Course 5), pp. 133-184.

Edwards, A. R., 1979. Classification of marine paleoenvironments. Geol. Soc. N.Z. Newsl., 47:17-19.
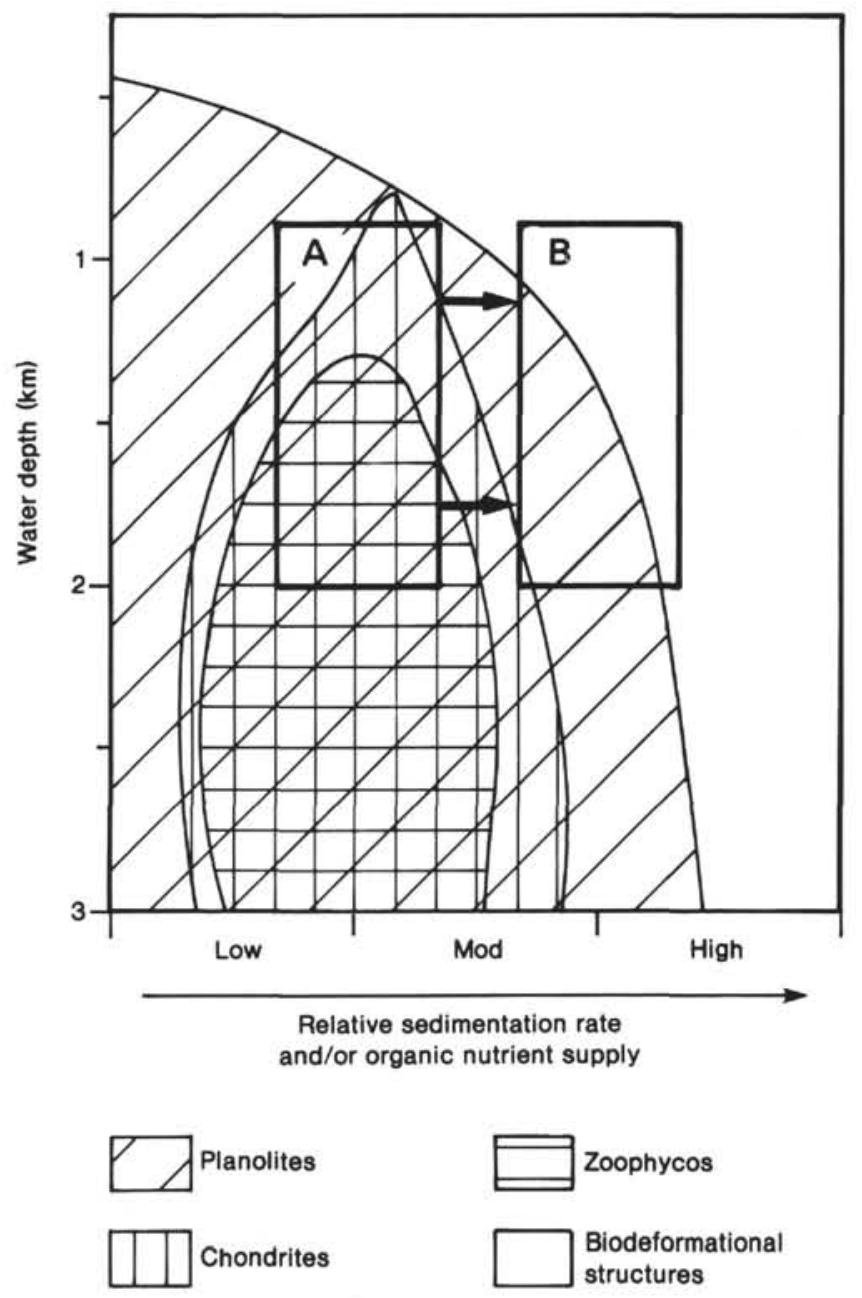

Figure 6. Schematic illustration of how changes in the relative rates of sedimentation and availability of organic nutrients at the seafloor could alone or together be responsible for the upward disappearance of the Planolites-Chondrites-Zoophycos assemblage in Leg 90 cores by passage from within area $\mathrm{A}$ to area B. The preferred environmental distribution fields for the various trace fossil types are adapted from those summarized by Werner and Wetzel (1981).

Ekdale, A. A., 1977. Abyssal trace fossils in worldwide Deep Sea Drilling Project cores. In Crimes, T. P., and Harper, J. C. (Eds.), Trace Fossils II: Liverpool (Seel House), pp. 163-182.

, 1978. Trace fossils in Leg 42A cores. In Hsü, K., Montadert, L., et al., Init. Repts. DSDP, 42, Pt. 1: Washington (U.S. Govt. Printing Office), 821-827.

, 1980. Trace fossils in Deep Sea Drilling Project Leg 58 cores. In Klein, G. deV., Kobayashi, K., et al., Init. Repts. DSDP, 58: Washington (U.S. Govt. Printing Office), 601-606.

Frey, R. W. (Ed.), 1975. The Study of Trace Fossils. New York (Springer Verlag).

Fullam, T. J., Supko, P. R., Boyce, R. E., and Stewart, R. J., 1973. Some aspects of late Cenozoic sedimentation in the Bering Sea and North Pacific Ocean. In Creager, J. S., Scholl, D. W., et al., Init. Repts. DSDP, 19: Washington (U.S. Govt. Printing Office), 887896.

Hantzschel, W., 1975. Trace fossils and problematica, In Teichert, C. (Ed.), Treatise on Invertebrate Paleontology, Part W, Supplement 1 , Miscellanea: Lawrence (University of Kansas and Geological Society of America).

Knox, G. A., 1970. Biological oceanography of the South Pacific. In Wooster, W. S., (Ed.), Scientific Exploration of the South Pacific: Washington (National Academy of Sciences), pp. 155-182. 
Lisitzin, A. P., 1972. Sedimentation in the world ocean. Soc. Econ. Paleontol. Mineral. Publ., 17.

McMillen, K. J., and Lundberg, N. F., 1982. Trace fossil assemblages in Leg 66 sediments. In Watkins, J. S., Moore, J. C., et al., Init. Repts. DSDP, 66: Washington (U.S. Govt. Printing Office), 653-657.

Müller, P. J., and Suess, E., 1979. Productivity, sedimentation rate, and sedimentary organic matter in the oceans-I. Organic carbon preservation. Deep-Sea Res., 26A:1347-1362.

Okado, H., 1980. Trace fossils in cores from Deep Sea Drilling Project Sites 434, 435, and 436 (Japan Trench Transect). In Scientific Party (Co-Chiefs: von Huene, R., Nasu, N., ), Init. Repts. DSDP, 56, 57, Pt. 2: Washington (U.S. Govt. Printing Office), 911-913.

Piper, D. J., and Schrader, J. H., 1973. Bioturbation of sediments. In Kulm, L. D., von Huene, R., et al., Init. Repts. DSDP, 18: Washington (U.S. Govt. Printing Office), 869-875.

Rochford, D. J., 1960a. The intermediate depth water of the Tasman and Coral Seas. I. The 27.20ot surface. Aust. J. Mar. Freshw. Res., 11:127-147.

$1960 \mathrm{~b}$. The intermediate depth water of the Tasman and Coral Seas, II. The 26.80ot surface. Aust. J. Mar. Freshw. Res., 11: 148-165.

Seilacher, A., 1978. Use of trace fossil assemblages for recognizing depositional environments. In Basan, P. (Ed.), Trace Fossil Con- cepts: Tulsa (Society of Economic Paleontologists and Mineralogists Short Course 5), pp. 167-181.

Suess, E., 1980. Particulate organic carbon flux in the oceans-surface productivity and oxygen utilization. Nature, 288:260-263.

Tracey, J. I., Jr., Sutton, G. H., et al., 1971. Site 71. In Tracey, J. I., Jr., et al., Init. Repts. DSDP, 8: Washington (U.S. Govt. Printing Office), 285-458.

van der Lingen, G. J., 1973. Ichnofossils in deep-sea cores from the Southwest Pacific. In Burns, R. E., Andrews, J. E., et al., Init. Repts. DSDP, 21: Washington (U.S. Govt. Printing Office), 693700.

Warme, J. E., Kennedy, W. J., and Schneidermann, N., 1973. Biogenic sedimentary structures (trace fossils) in Leg 15 cores. In Edgar, N. T., Saunders, J. B., et al., Init. Repts. DSDP, 15: Washington (U.S. Govt. Printing Office), 813-831.

Werner, F., and Wetzel, A., 1981. Interpretation of biogenic structures in oceanic sediments. Bull. Inst. Geol. Bassin d'Aquitaine, Bordeaux, 31:275-288.

Date of Initial Receipt: 25 June 1984

Date of Acceptance: 31 October 1984 


\section{S. NELSON}
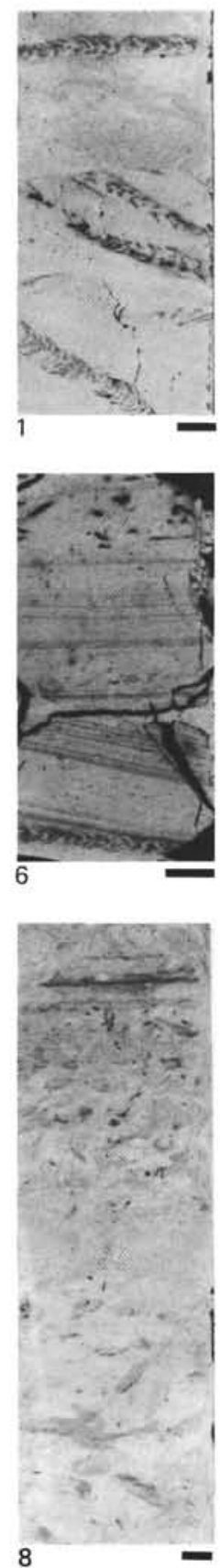
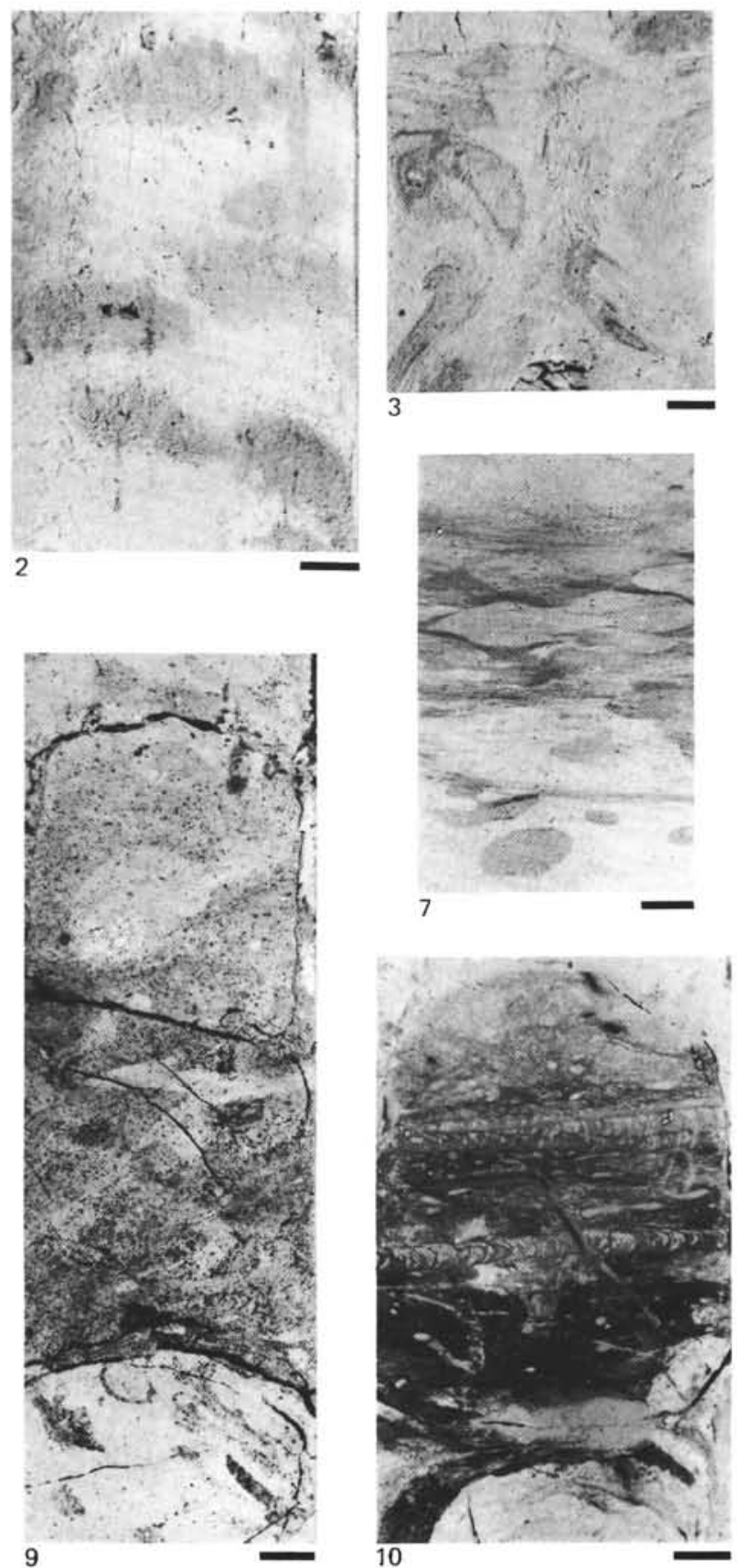
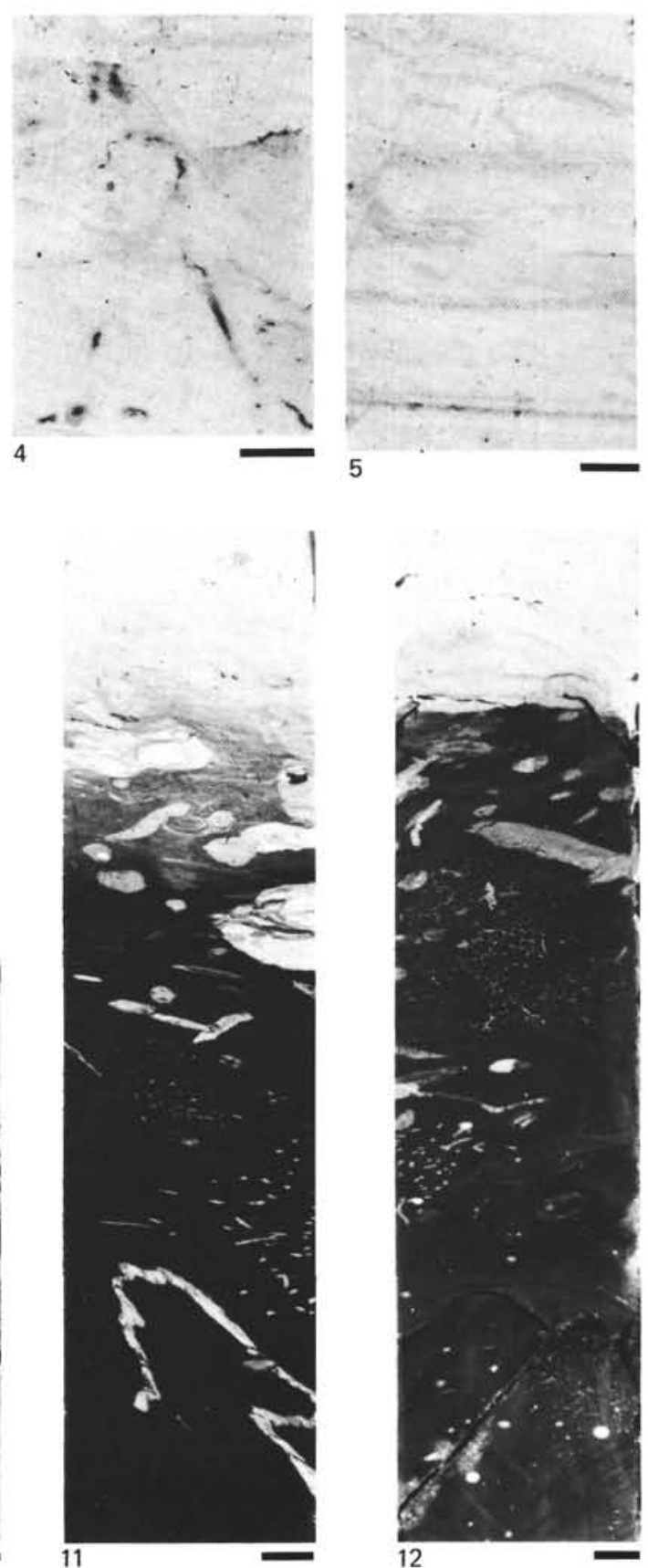

Plate 1. Examples of biogenic traces in Leg 90 calcareous oozes and chalks. Bar scale equals $1 \mathrm{~cm}$. 1. 594A-13-1, 131-142 cm, showing Zoophycos spreiten and diffuse blebs and mottles of Planolites-like burrows in chalk. 2. 588-12-5, 31-41 cm, showing diffuse Planolites-like yellowish gray burrow mottles in soft white ooze. 3. 591B-9-2, 52-60 cm, showing Planolites and halo burrows smeared by coring in soft chalk. 4. 591B-6-5, 94-100 cm, showing pyritized spots, threads and halo burrows, and diffuse burrows in chalk with vaguely discernible small normal fault at top right. 5. 591B-7-3, 19-27 cm showing diffuse Zoophycos, Planolites-like, and ?Chondrites traces in chalk offset by small normal fault at top left. Pyritized lamina near base. 6. 588C-13-6, 71-80 cm, showing Chondrites burrows and a Zoophycos trace in chalk with pale greenish gray laminae formed from altered volcanic ash materials. 7. 591B-18-3, 83-92 cm, showing common Planolites burrows in chalk with prominent flaser-like structures formed by selective dissolution and cementation processes, possibly controlled partly by burrow morphology and distribution. 8. 590B-44-1, 128-148 cm, showing diffuse color blebs and mottles, and streaks and wisps in moderately intensely burrowed chalk. 9. 588C-4-6, 20-37 cm, showing complex color mottling and common pyritized spots associated with Planolites, Chondrites, and rind burrows in intensely bioturbated altered ?ash bed overlying chalk. 10. 594A-13-2, 128-139 cm, showing Planolites-Chondrites-Zoophycos assemblage of trace fossils in silty sponge spicule-bearing interbed in chalk. 11. 594A-24-1, 37-58 cm, showing coarse ecologic stratification of Planolites, Chondrites, and Zoophycos (or ?Teichichnus) in top of redeposited interbed (dark) of silt and clay-bearing chalk in pure chalk (white). 12. 594A-25-1, 76-100 cm, as for Fig. 11, although depth of reworking by Chondrites and Planolites-like burrows is more variable. 